\title{
Warming reduces tall fescue abundance but stimulates toxic alkaloid concentrations in transition zone pastures of the U.S.
}

\author{
Rebecca L. McCulley*, Lowell P. Bush, Anna E. Carlisle, Huihua Ji and Jim A. Nelson
}

Department of Plant and Soil Sciences, University of Kentucky, Lexington, KY, USA

Edited by:

James Levi Klotz, United States

Department of Agriculture, USA

\section{Reviewed by:}

Chuck West, Texas Tech University, USA

Jonathan A. Newman, University of Guelph, Canada

\section{*Correspondence:}

Rebecca L. McCulley, Department of Plant and Soil Sciences,

University of Kentucky, N-222D Ag. Science North, Lexington, $K Y$ 40546-0091, USA

e-mail: rebecca.mcculley@uky.edu
Tall fescue pastures cover extensive acreage in the eastern half of the United States and contribute to important ecosystem services, including the provisioning of forage for grazing livestock. Yet little is known concerning how these pastures will respond to climate change. Tall fescue's ability to persist and provide forage under a warmer and wetter environment, as is predicted for much of this region as a result of climate change, will likely depend on a symbiotic relationship the plant can form with the fungal endophyte, Epichloë coenophiala. While this symbiosis can confer environmental stress tolerance to the plant, the endophyte also produces alkaloids toxic to insects (e.g., lolines) and mammals (ergots; which can cause "fescue toxicosis" in grazing animals). The negative animal health and economic consequences of fescue toxicosis make understanding the response of the tall fescue symbiosis to climate change critical for the region. We experimentally increased temperature $\left(+3^{\circ} \mathrm{C}\right)$ and growing season precipitation $(+30 \%$ of the long-term mean) from 2009-2013 in a mixed species pasture, that included a tall fescue population that was $40 \%$ endophyte-infected. Warming reduced the relative abundance of tall fescue within the plant community, and additional precipitation did not ameliorate this effect. Warming did not alter the incidence of endophyte infection within the tall fescue population; however, warming significantly increased concentrations of ergot alkaloids (by 30-40\%) in fall-harvested endophyte-infected individuals. Warming alone did not affect loline alkaloid concentrations, but when combined with additional precipitation, levels increased in fall-harvested material. Although future warming may reduce the dominance of tall fescue in eastern U.S. pastures and have limited effect on the incidence of endophyte infection, persisting endophyte-infected tall fescue will have higher concentrations of toxic alkaloids which may exacerbate fescue toxicosis.

Keywords: climate change, Epichloë coenophiala, ergot alkaloids, loline alkaloids, Lolium arundinaceum, pasture sustainability

\section{INTRODUCTION}

Tall fescue [Lolium arundinaceum (Schreb.) Darbysh, a.k.a. Festuca arundinacea (Schreb.), and Schedonorus arundinaceus (Schreb.) Dumort.] is a $\mathrm{C}_{3}$ physiology, cool-season perennial grass that was introduced to North America from Eurasia in the late 1800 s, but today covers more than 14 million hectares, primarily in the eastern half of the United States (Ball et al., 1993; Hoveland, 2009; Young et al., 2013). In this region, tall fescue is widely utilized as a forage in pasture-based livestock systems, in part due to its ease of establishment, environmental hardiness, and ability to persist and produce forage under a range of management regimes (Roberts et al., 2009). Many of these attributes are linked to a symbiotic relationship the plant can form with an asymptomatic, asexual fungal endophyte-Epichloë coenophiala (a.k.a., Neotyphodium coenophialum; Clay, 1990; Schardl et al., 2004; Leuchtmann et al., 2014).

Similar grass-fungal endophyte relationships are common (Arnold et al., 2000), occurring on every continent except
Antarctica and within $20-30 \%$ of grass species (White, 1987; Leuchtmann, 1992). The nature of these relationships varies across the symbiotic continuum (Saikkonen et al., 1998), depending on plant and fungal genetics and biotic and abiotic environmental parameters (Cheplick and Faeth, 2009). While the relationship between tall fescue and E. coenophiala is generally considered mutualistic (Clay, 1990), prior work suggests that the benefits of fungal endophyte infection to the plant might be most pronounced under conditions of high herbivory (Bouton et al., 1993; Clay et al., 2005), high or low nutrient availability (Malinowski and Belesky, 2000; Rahman and Saiga, 2005), and/or at times of extreme heat or water limitation, such as commonly occurs during summer droughts (Arachevaleta et al., 1989; Elbersen and West, 1996; Marks and Clay, 1996; Assuero et al., 2006).

Tall fescue is thought to provide food, shelter, and a means of reproduction for the fungus, as E. coenophiala can only infect new tall fescue individuals through vertical, mother-daughter 
transmission (Clay and Schardl, 2002; Schardl et al., 2004). While in return, the fungus produces a suite of alkaloids, including peramines, lolines, and ergots-some of which are known to deter herbivory (Bush et al., 1997). Because these fungal-produced alkaloids are toxic to some herbivores, their presence can alter herbivory [e.g., cause increased consumption of surrounding endophyte-free (E-) individuals or other plant species] such that a significant competitive advantage is conferred to endophyteinfected (E+) tall fescue (Clay and Holah, 1999; Clay et al., 2005). Unfortunately, grazing livestock are susceptible to these alkaloids, and significant negative animal health issues arise when animals are forced to graze infected tall fescue material, particularly during times of temperature stress (i.e., fescue toxicosis in the southeastern U.S.; Stuedemann and Hoveland, 1988; Hoveland, 1993; Strickland et al., 2011).

However, the tall fescue-E. coenophiala symbiosis is not just a defensive mutualism (Clay and Schardl, 2002). While studies have shown that in situations where herbivory levels are high, the percentage of fungal endophyte infected individuals within a tall fescue community can increase over time (Clay et al., 2005), fungal endophyte infection frequencies (EIF) have also been shown to vary in relation to environmental stress (Lewis et al., 1997). Higher EIF are frequently encountered in harsher environments (West et al., 1993), and for tall fescue, survival, and recovery following exposure to high temperatures and water limitation are often enhanced by endophyte infection (Elmi and West, 1995; Elbersen and West, 1996; Marks and Clay, 1996; Belesky and West, 2009). Such results suggest that endophyte infection may improve tall fescue's ability to resist and adapt to environmental perturbations that are likely to result from climate change-a supposition made for many symbiotic associations (Compant et al., 2010; Redman et al., 2011; Kivlin et al., 2013).

Only a few studies to date have experimentally evaluated this possibility for tall fescue and results are mixed. Endophyte infection sometimes alters tall fescue response to elevated atmospheric $\mathrm{CO}_{2}$ (Newman et al., 2003) but not always (Chen et al., 2007). Effects of endophyte infection on plant recovery and survival following drought and temperature stress, while somewhat variable, tend to be positive for tall fescue (Arachevaleta et al., 1989; Marks and Clay, 1996; Worchel et al., 2013). Elevated $\mathrm{CO}_{2}$ has been shown to reduce, while drought and increased temperature stimulate, alkaloid concentrations in E+ material (Agee and Hill, 1994; Brosi et al., 2011b; Ryan et al., 2014). Long-term field manipulations of multiple climate change factors are rare, and yet they are essential to understanding how complex systems will respond (Backlund et al., 2008). In one such study, Brosi et al. (2011b) found that elevated $\mathrm{CO}_{2}$ led to a higher EIF within the tall fescue community of a mixed species, unmanaged old field after 5 years of experimental manipulation, but surprisingly, measured no change in EIF under drought or elevated temperature treatments or their interactions. Unfortunately, this study could not capture changes in tall fescue-endophyte dynamics over time and was not representative of pasture conditions (species- or management-wise); therefore, implications from it for tall fescue pastures are limited.

Given that tall fescue is a dominant component of pastures across extensive acreage in the eastern U.S., and serves as the forage base for a multi-million dollar animal industry, which suffers substantially from the negative effects of fungal-produced alkaloids, it is important to understand how potential changes in climate will impact the fescue-endophyte symbiosis. This project evaluated the consequences of warming $\left(+3^{\circ} \mathrm{C}\right.$, day and night, year-round) and increased growing season precipitation $(+30 \%$ of the long-term mean), conditions that are representative of current climate projections for this region (Brunjes, 2004; Karl et al., 2009), on tall fescue abundance, EIF, and alkaloid concentrations over a 5 years period in a hay-managed, mixed species pasture in central Kentucky. Because tall fescue is a cool season grass and the warming treatment was expected to increase the intensity and duration of seasonal dry periods normally experienced at the site, we anticipated that warming would decrease tall fescue abundance, especially in mid-summer and early fall, and that this environmental stress would select for $\mathrm{E}+$ individuals and thereby increase the level of endophyte infection within the tall fescue community over time. We also hypothesized that warming would stimulate alkaloid concentrations in $\mathrm{E}+$ individuals and that the addition of precipitation would ameliorate some of these effects of warming on the plant and its symbiotic partner.

\section{MATERIALS AND METHODS SITE DESCRIPTION}

The climate change project was established in an existing pasture, on relatively deep $(>1 \mathrm{~m})$ Maury silt loam soils, located at the University of Kentucky's Spindletop Farm, Lexington, KY, USA $\left(38.1081^{\circ} \mathrm{N} ; 84.4916^{\circ} \mathrm{W}\right)$. The site is situated in a transition zone between subtropical and continental climates, experiencing longterm mean annual summer and winter temperatures of 23.8 and $1.6^{\circ} \mathrm{C}$, respectively (Ferreira et al., 2010), with rainfall relatively evenly distributed throughout the year, averaging $1137 \mathrm{~mm}$ a year. Average annual temperatures $\left({ }^{\circ} \mathrm{C}\right)$ and total annual rainfall $(\mathrm{mm})$ were as follows, respectively, over the 5 years project: $2009-12.7$, 1323; 2010-13.2, 1048; 2011-13.4, 1656; 2012-14.4, 1019; and 2013-12.8, 1495 (Kentucky Mesonet-Lexington).

In March and April 2008, the pasture was sprayed with glyphosate, plowed, and disked to remove existing vegetation and to prepare a seedbed. A seed mixture consisting of cool season, $\mathrm{C}_{3}$ physiology forage species common to the area were planted on April 8, 2008 and consisted of: Kentucky bluegrass (Poa pratensis, cultivar "Ginger"), tall fescue (cultivar "Kentucky31 "), red clover (Trifolium pretense, cultivar "Freedom"), and white clover (Trifolium repens, cultivar "Patriot"). For tall fescue, $50 \%$ of the seed was infected with the common toxic strain of E. coenophialum and 50\% was not infected (i.e., was Epichloëfree). On August 22, 2008, the warm-season, $\mathrm{C}_{4}$ physiology forage grass, Bermuda (Cynodon dactylon, cultivar "Wrangler"), was plugged throughout the establishing stand. Plugs originated from an existing adjacent field. For more details on site characteristics and stand establishment see Brosi (2011a), Slaughter (2012), and Bourguignon (2013).

\section{EXPERIMENTAL DESIGN}

Within the newly established stand $\left(\sim 1500 \mathrm{~m}^{2}\right)$, five replicate blocks, similar in vegetative composition and large enough to contain four, $3 \mathrm{~m}$ diameter $\left(5.8 \mathrm{~m}^{2}\right)$ plots, were 
identified. Plots within a block were randomly assigned to one of four climate treatments: theat $\left(+3^{\circ} \mathrm{C}\right.$ above ambient temperature); +precip ( $+30 \%$ long-term normal precipitation; $+343 \mathrm{~mm}$ ); +heat+precip (the combination of the first two treatments); and an untreated, ambient control. The theat treatment was achieved by following the approach of Kimball et al. (2008). Salamander infrared ceramic heaters (Mor Electric Heating Assoc., Comstock Park, MI) were positioned around each plot, and heat was applied as needed to maintain the desired $+3^{\circ} \mathrm{C}$ difference between the theat plot and its paired ambient temperature comparison (control plots for theat treatment and +precip plots for the + heat+precip treatment). To control for potential shade effects from the heaters, all plots were surrounded by the housing units used to mount them. For the + precip treatment, rainfall collected on-site was applied using a metered wand, twice a month, on rainy days, during the growing season only (April to September). Quantities of additional precipitation applied each month were based on long-term rainfall trends for the site and were constant across years of the experiment (April $+50.8 \mathrm{~mm}$; May $+50.8 \mathrm{~mm}$; June $+61.7 \mathrm{~mm}$; July $+67.0 \mathrm{~mm}$; August $+61.7 \mathrm{~mm}$; September $+50.8 \mathrm{~mm}$ ). Aluminum sheeting was inserted into the soil to $50 \mathrm{~cm}$ depth around individual plots to minimize movement of soil moisture into or out of the plots. Climate treatments began May 1, 2009 and ran continuously until November 12, 2013.

\section{MEASUREMENTS}

Effects of the climate treatments on air temperature and soil moisture were measured continuously throughout the experiment. Air temperature was measured every $15 \mathrm{~s}$ at $30 \mathrm{~cm}$ above the ground surface with shielded Type T thermocouples (FW3648, TE Wire, Saddle Brook, NJ). Volumetric water content of the top $15 \mathrm{~cm}$ of soil was measured every $15 \mathrm{~min}$ using time domain reflectrometers (CS-616, Campbell Scientific, Logan, UT). Daily, monthly, and seasonal averages of these data for each treatment were computed.

The experiment was managed as a hay field, meaning that all vegetation was mowed to a height of $7.6 \mathrm{~cm}$, and cut material was removed off site. For all years of the project, mowing occurred three times per growing season. Climate treatment effects on total aboveground plant biomass production (data not shown) and the biomass and relative abundance of tall fescue were obtained from seasonal sub-plot harvests that immediately preceded whole-plot mowing events. All vegetation located within two, $0.25 \mathrm{~m}^{2}$ permanent sub-plots per plot was cut to $7.6 \mathrm{~cm}$ height, removed, and sorted by hand to species. This material was then oven-dried $\left(55^{\circ} \mathrm{C}\right.$ for $3-4$ days) and weighed. The relative abundance of tall fescue was calculated on a biomass basis: tall fescue biomass/total biomass per sub-plot. Sub-plot values were averaged for a plot value for subsequent statistical analyses. Harvests occurred on the following dates: 2009 (June 1, July 21, Sept. 22); 2010 (May 17, July 26, Oct. 5); 2011 (May 23, July 25, Oct. 5); 2012 (May 21, July 30, Oct. 8); and 2013 (May 21, Aug. 5, Oct. 14).

In order to determine whether the climate treatments were affecting the occurrence of $\mathrm{E}+$ and $\mathrm{E}-$ individuals within the tall fescue population, $\sim 40$ tall fescue tillers per plot were harvested by hand, at $7.6 \mathrm{~cm}$ above ground level, with a razor blade, immediately preceding all spring and fall harvests. These tillers were kept cold in a freezer $\left(-4.0^{\circ} \mathrm{C}\right)$ until they could be processed for endophyte presence (usually within 1-2 weeks). We utilized an enzyme-linked, endophyte-specific immunosorbent assay to determine whether individual tillers were $\mathrm{E}+$ or $\mathrm{E}-$ (Hiatt et al., 1999). Each tiller was individually labeled and double-blotted onto nitrocellulose paper that was then assayed for the presence of the endophyte-specific immunoprotein. If the endophyte protein was present, a color reaction would occur, and tiller blots would turn pink. They remained colorless if no endophyte protein was detected. Plot-level tall fescue EIF was calculated as the number of tillers testing positive for the presence of the endophyte divided by the total number of tillers tested per plot. One person scored all the blots as either positive or negative for the entire project, and positive and negative controls were run with each batch. Because, like others (Ju et al., 2006), we detected regular seasonal patterns in EIF (spring values usually lower than fall values, across all treatments; data not shown), we present only the initial June 2009 and all following fall EIF data. Our treatment-related EIF results do not change if all data are included in the statistical models. Fescue tillers were lyophilized once the blots were scored.

Because only the fungal endophyte can produce the insect and mammal toxic alkaloids we were interested in measuring (Bush et al., 1997), the immunoblot results were used to separate the E+ tillers from the E- before alkaloid analysis. Only E+ tillers were composited per plot, ground to pass through a $1 \mathrm{~mm}$ screen using a Cyclotec 1093 mill, and analyzed for loline and ergot alkaloid concentrations. Due to lab error, we did not measure alkaloids on the first fescue tiller harvest (June 2009), but they were measured on all E+ tillers collected thereafter. Gas chromatography (GC) was used to identify and quantify three loline compounds $(N$ formyl loline, $N$-acetyl loline, and $N$-acetyl norloline), according to the protocol of Blankenship et al. (2001). A $0.3 \mathrm{~g}$ sub-sample of ground material was extracted in sodium bicarbonate and methylene chloride containing quinoline $\left(15 \mu \mathrm{g} \mathrm{mL}^{-1}\right.$; an internal standard) via shaking for an hour. Extracts were filtered and analyzed on a GC (Perkin Elmer Clarus 500) equipped with a flame ionized detector and using an SPB-1 fused silica capillary column $(15 \mathrm{~m} \times 0.53 \mathrm{~mm}, 0.5 \mu \mathrm{m}$ film thickness; Supelco $)$. The GC temperature program increased from 80 to $160^{\circ} \mathrm{C}$ at $20^{\circ} \mathrm{C}$ $\mathrm{min}^{-1}$, was held for $2 \mathrm{~min}$, was increased to $290^{\circ} \mathrm{C}$ at $45^{\circ} \mathrm{C} \mathrm{min}{ }^{-1}$, and held for $5 \mathrm{~min}$. Injector and detector temperatures were set at 250 and $275^{\circ} \mathrm{C}$, respectively.

High performance liquid chromatography (HPLC) with florescence detection was employed to quantify ergovaline and ergovalinine concentrations, as developed by Yates and Powell (1988). A $0.1 \mathrm{~g}$ ground sample was extracted in $80 \%$ methanol via shaking for $2 \mathrm{~h}$. The extractant was then forced, by syringe, through a PreSep column (SPE, C18 disposable) fitted with a $0.2 \mu \mathrm{m}$ polytetrafluoroethylene filter. The third $\mathrm{mL}$ aliquot of extractant was isolated and eluted with the following solutions: (A) $0.1 \mathrm{M}$ ammonium acetate: acetonitrile, 97:3 v/v and (B) 100\% acetonitrile. A reverse phase Kinetex XB-C18 column $(100 \times 4.6 \mathrm{~mm}$ with $2.6 \mu \mathrm{m}$ particle size) was used to separate compounds at a flow of $1.2 \mathrm{~mL} \mathrm{~min}^{-1}$ with the following gradient conditions: initial $22 \%$ mobile phase B increased linearly to $35 \%$ over 20 min and then further linearly to $58 \% \mathrm{~B}$ in $8 \mathrm{~min}$ before being increased 
to $100 \% \mathrm{~B}$ and held for $5 \mathrm{~min}$. After this period, re-equilibration was achieved by reducing to $22 \% \mathrm{~B}$ for $9 \mathrm{~min}$. Ergovaline and ergovalinine were identified by excitation at 310 and emission measurement at $420 \mathrm{~nm}$ and had retention times of 14.1 and $24.4 \mathrm{~min}$, respectively. Endophyte-free samples were included as checks periodically and consistently had non-detectable levels of all the compounds of interest. Independently verified $\mathrm{E}+$ material, not associated with this project, was run during all analyses as a lab standard.

\section{STATISTICAL ANALYSIS}

The randomized complete block design of the project included five replicates of four climate change treatments that were implemented in a $2 \times 2$ factorial design ( + heat $\times+$ precip), with measurements taken over a 5-years period of time. Therefore, we statistically analyzed majority of our data with a repeated measures analysis of variance mixed linear model using the restricted maximum likelihood method within Proc Mixed procedures of SAS version 9.3 (SAS Institute Inc., Cary, NC). Main, fixed effects were designated as heat, precip, time, and all interactions therein. Block was the random effect, and the repeated subject was block by climate treatment. All parameters were tested for normality and homogeneity of variance and adjusted, if necessary, as follows.

The time variable, and therefore the repeated measure, differed across parameters. For air temperature and soil moisture, average seasonal values were calculated for each year (Spring-March, April, May; Summer-June, July, August; FallSeptember, October, November; Winter-December, January, February). Because we knew years varied significantly in these parameters, we analyzed this seasonal data by year (2009-2013) using a multiple analysis of variance model (Proc GLM; SAS v.9.3), with block, heat, and precipitation as main effects and season as the repeated variable. For tall fescue relative abundance, harvest period (Spring, Summer, and Fall) and year were included as the time variables in the models. For alkaloid concentrations, material sampled was from two seasons (Spring and Fall) over the 5 years, so both season and year were included in the models.

To determine whether changes in EIF occurred over time in the climate treatments, we used time as a continuous measure (months since experiment began), and calculated the difference in EIF between the month of measure and the initial infection frequency on a per plot basis, which was then analyzed with the same model as the other parameters. To assess whether differences in EIF existed at the start of the experiment, the June 2009 EIF data were angular transformed, to meet assumptions of the model, and run with heat, precip, and their interaction as main effects, block as the random effect, and no repeated statement. There were no significant differences in EIF across plots at the initial measurement period (all $p>0.4)$, with the site averaging $41.1 \%( \pm 3.3)$ of fescue tillers infected.

For significant main effects and interactions ( $p<0.05)$, mean comparisons were performed with lsmeans using either the pdiff or the Dunnett multiple comparison adjustment (for EIF data only). Because we did not measure alkaloids the first spring (2009), we ran means comparison tests on these data with year 2009 excluded. For air temperature and soil moisture data,
Type I sums of squares were used to generate p-values for the climate treatment effects (heat, precip, and their interaction), and for season and its interactions with the climate treatments, Hotelling-Lawley Trace method was used to generate the p-values.

\section{RESULTS}

\section{AIR TEMPERATURE AND SOIL MOISTURE}

As expected, given the intention of the climate manipulations, air temperatures were increased by $3.04 \pm 0.17^{\circ} \mathrm{C}$ in + heat plots vs. the ambient temperature treatments, averaged $( \pm S E)$ across the entire 5-years project (Figure 1). Increases in air temperature due to warming were greater during the summer $\left(3.87 \pm 0.22^{\circ} \mathrm{C}\right)$ than the winter $\left(1.63 \pm 0.13^{\circ} \mathrm{C}\right)$, explaining the significant season $\times$ heat effect in all years of the project (Table 1), but the magnitude of this seasonal effect varied across years (Figure 1).

Warming reduced soil moisture by $13.9 \%$ averaged over the duration of the project, but this effect was strongest during the summer period, especially in the drier years-2010 and 2012 (Figure 1, Table 1). The + precip treatment mediated, to some degree, the effects of warming during the summer dry-down period: +heat+precip plots averaged $24.3 \%$ more soil moisture during the summer than +heat plots. However, +heat+precip plots rarely had greater soil moisture then ambient control plots (Figure 1). Plots receiving only the + precip treatment were the wettest, especially during the summer, when the additional water was being applied (averaging 15.2-50.7\% more soil moisture than ambient controls or theat treatments in all summers of the project). Soils were generally wettest in the winter and driest during the summer, though considerable year-to-year variability in soil moisture was encountered [average annual (or less than annual in some years) soil moisture across treatments \pm SE: $31.1 \pm 0.12 \%-2009$ (June-Dec.); $24.8 \pm 0.14 \%-2010 ; 28.7 \pm$ $0.27 \%-2011 ; 23.3 \pm 0.30 \%-2012 ;$ and $27.6 \pm 0.14 \%-2013$ (Jan.-Oct.)]. In 2011, the wettest year of the project, additional precipitation had no effect on soil moisture, even during the summer (although the season $\times$ precip interaction was significant, means comparison tests failed to identify a significant comparison), but slightly cooled the plots receiving this treatment (Table 1).

\section{TALL FESCUE RELATIVE ABUNDANCE AND ENDOPHYTE INFECTION FREQUENCY}

Warming significantly reduced tall fescue relative abundance across the entirety of the project, except for the Spring 2012 harvest period when there was no significant difference between theat and non-heated treatments (Figure 2). Even in June (Spring) 2009, after only a month of +heat treatments, tall fescue relative abundance was depressed by $\sim 35 \%$ compared to non-heated plots. This immediate treatment effect did not reflect pre-existing differences in tall fescue abundance across plots, as visual cover estimates made in October 2008 indicated treatments were similar: $23.6 \%$ tall fescue $\pm 3.8-$ control; $26.3 \% \pm 9.0$ - +heat; $27.6 \% \pm 4.3$ - + precip; $24.0 \% \pm$ 4.3 - +heat+precip; and $25.6 \%$ vs. $25.2 \%$ for ambient temperature treatments vs. heated (average $\pm \mathrm{SE}$ ). Tall fescue relative abundance increased for both + heat and non-heated plots after 


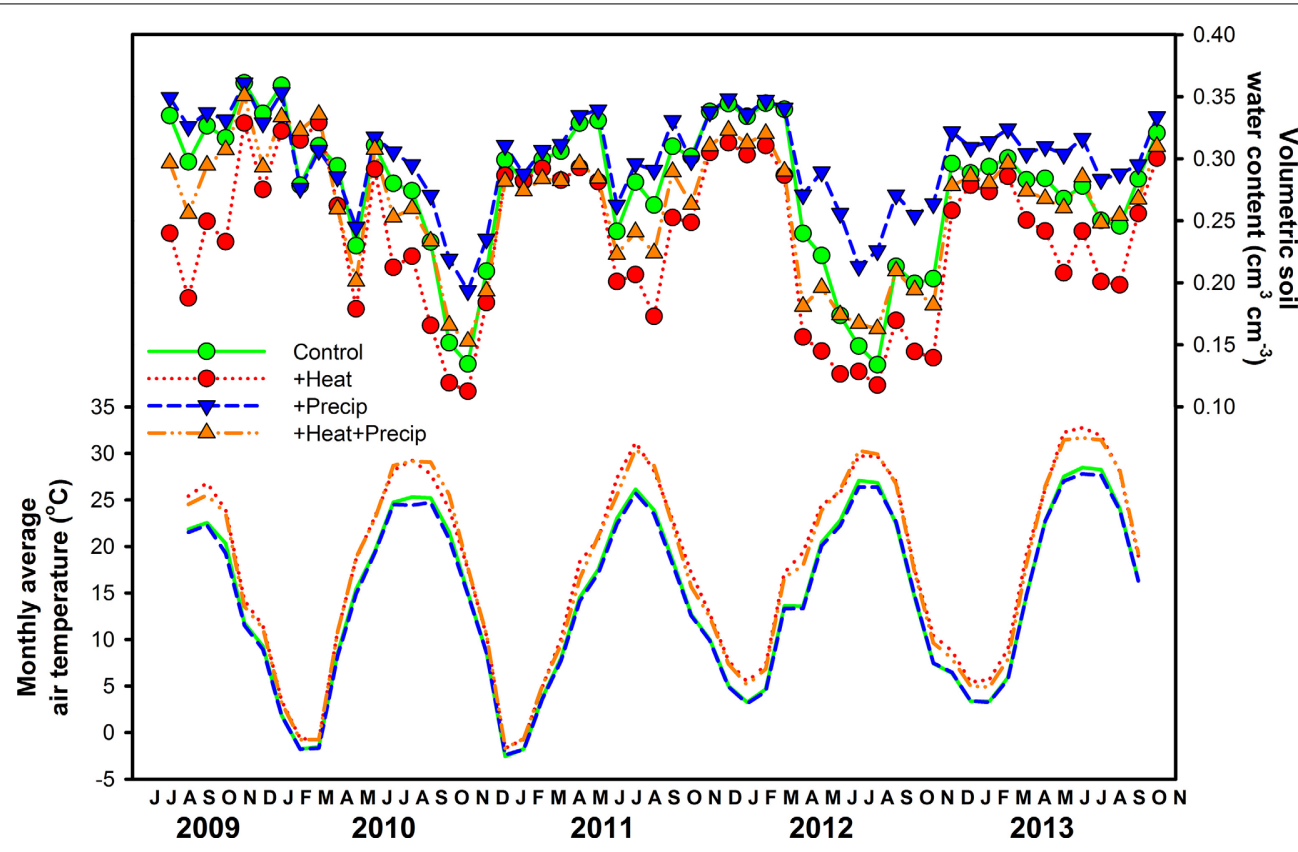

FIGURE 1 | Average ( \pm SE) monthly air temperature (lines only) and volumetric soil moisture (0-15 cm; lines plus symbols) measured in each plot of the four climate treatments (ambient control, +heat, +precip, +heat+precip) across the 5 years study period.

Table 1 | Statistical results of the effects of season, the climate treatments (+heat and +precip), and their interactions on air temperature and soil moisture across the 5-years project period, 2009-2013.

\begin{tabular}{|c|c|c|c|c|c|c|c|c|c|c|c|c|c|c|c|}
\hline Effect & \multicolumn{3}{|c|}{2009} & \multicolumn{3}{|c|}{2010} & \multicolumn{3}{|c|}{2011} & \multicolumn{3}{|c|}{2012} & \multicolumn{3}{|c|}{2013} \\
\hline Heat & 1 & 102.92 & $<0.0001$ & 1 & 195.18 & $<0.0001$ & 1 & 260.61 & $<0.0001$ & 1 & 160.31 & $<0.0001$ & 1 & 87.20 & $<0.0001$ \\
\hline Prec & 1 & 3.04 & 0.1069 & 1 & 0.00 & 0.9839 & 1 & 5.13 & 0.0429 & 1 & 1.41 & 0.2577 & 1 & 0.70 & 0.4180 \\
\hline Heat*Prec & 1 & 0.23 & 0.6386 & 1 & 2.30 & 0.1556 & 1 & 0.62 & 0.4447 & 1 & 0.20 & 0.6638 & 1 & 0.03 & 0.8603 \\
\hline Seas*Prec & 2,11 & 2.12 & 0.1666 & 3,10 & 0.51 & 0.6815 & 3,10 & 1.86 & 0.2005 & 3,10 & 1.97 & 0.1826 & 2,11 & 2.65 & 0.1150 \\
\hline Seas*Heat*Prec & 2,11 & 0.55 & 0.5918 & 3,10 & 3.25 & 0.0682 & 3,10 & 0.71 & 0.5684 & 3,10 & 5.49 & 0.0172 & 2,11 & 0.22 & 0.8040 \\
\hline \multicolumn{16}{|l|}{ SOIL MOISTURE } \\
\hline Heat & 1 & 33.07 & $<0.0001$ & 1 & 14.82 & 0.0023 & 1 & 11.26 & 0.0057 & 1 & 17.06 & 0.0014 & 1 & 7.77 & 0.0164 \\
\hline Prec & 1 & 11.03 & 0.0061 & 1 & 6.60 & 0.0246 & 1 & 1.03 & 0.3302 & 1 & 9.85 & 0.0086 & 1 & 5.79 & 0.0331 \\
\hline Seas*Heat*Prec & 2,11 & 2.78 & 0.1053 & 3,10 & 9.98 & 0.0024 & 3,10 & 0.85 & 0.4996 & 3,10 & 3.36 & 0.0633 & 2,11 & 3.10 & 0.0855 \\
\hline
\end{tabular}

Significant $p$-values are bolded.

the first year (by 217 and 132\%, respectively) and remained relatively stable across years thereafter (averaging 36.4\% across treatments). Tall fescue was most abundant in the Spring harvests for all treatments, and the difference between ambient temperature and theat plots increased as the growing season progressed from Spring to the Summer and Fall harvests across all years of the study. Surprisingly, despite the + precip treatment increasing soil moisture by $8.5,21.7$, and $12.9 \%$ over control, theat, and +heat+precip, respectively, over the course of the study, tall fescue relative abundance was not significantly affected by the addition of precipitation alone ( $p=0.1029$; Table 2$)$. Although added precipitation increased soil moisture in the +heat + precip treatment over that of the +heat alone (by $11.2 \%$ over the course of the study), especially in summer, only a marginally significant 


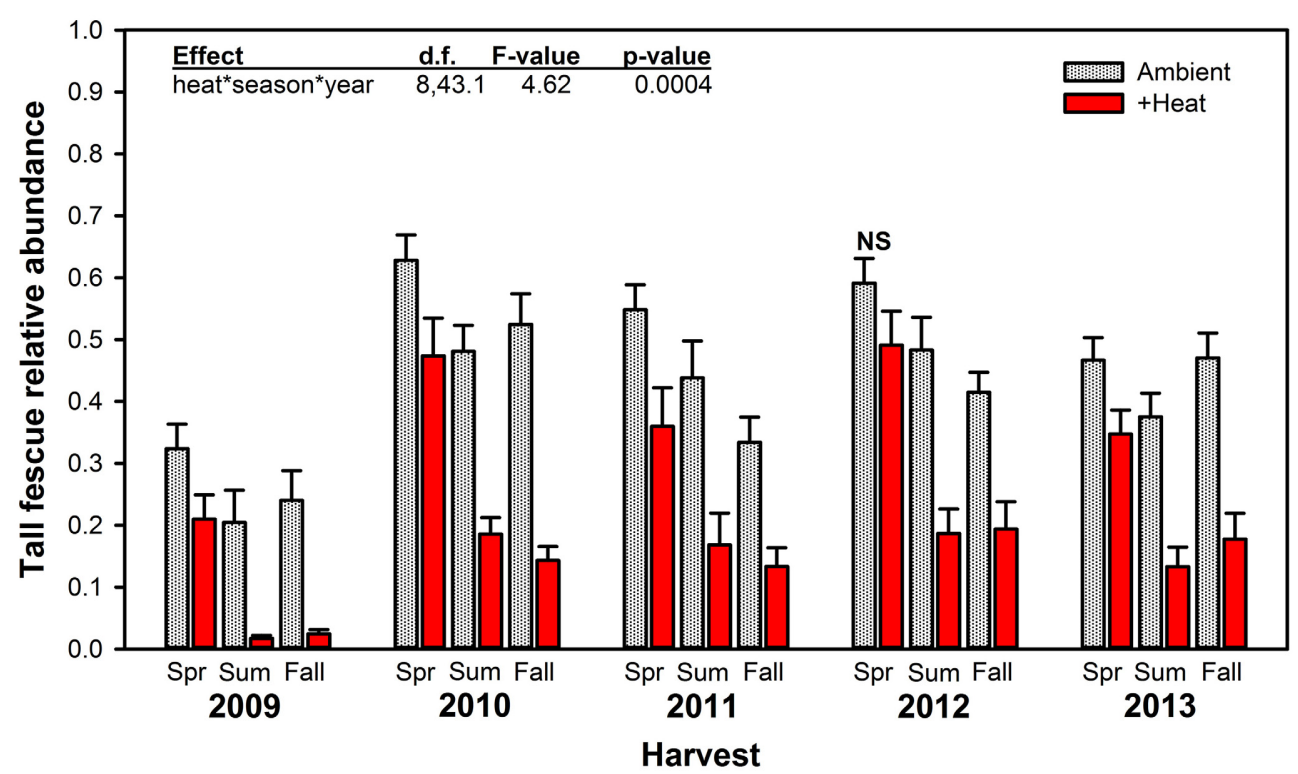

FIGURE 2 | Average $( \pm S E)$ relative abundance of tall fescue (g tall fescue biomass $/ g$ total biomass) measured in heated $\left(+3^{\circ} \mathrm{C}\right)$ vs. non-heated, ambient temperature treatments at every harvest period (Spring, Summer, and Fall) for all $\mathbf{5}$ years of the study. The highest order significant interaction among the main effects of heat, season, and year is provided (see Table 2 for full statistical results). NS indicates the only harvest period where significant effects of heat were not observed.
Table 2 | Statistical results of the effects of the climate treatments (+heat and +precip), season, year, and their interactions on tall fescue relative abundance in a mixed species pasture.

\begin{tabular}{lccr}
\hline Effect & Num,Den $\boldsymbol{d f}$ & $\boldsymbol{F}$-value & Pr $>\boldsymbol{F}$ \\
\hline Heat & $1,33.7$ & 51.68 & $\mathbf{2 0 . 0 0 0 1}$ \\
Precip & $1,33.7$ & 2.81 & 0.1029 \\
Heat*Precip & $1,33.7$ & 3.96 & 0.0546 \\
Season & $2,24.4$ & 75.29 & $<\mathbf{0 . 0 0 0 1}$ \\
Heat*Season & $2,24.4$ & 9.33 & $\mathbf{0 . 0 0 1 0}$ \\
Precip*Season & $2,24.4$ & 1.89 & 0.1729 \\
Heat*Precip*Season & $2,24.4$ & 1.16 & 0.3317 \\
Year & $4,26.6$ & 48.10 & $<\mathbf{0 . 0 0 0 1}$ \\
Heat*Year & $4,26.6$ & 1.87 & 0.1449 \\
Precip*Year & $4,26.6$ & 1.49 & 0.2344 \\
Heat*Precip*Year & $4,26.6$ & 0.21 & 0.9283 \\
Season*Year & $8,43.1$ & 12.51 & $<\mathbf{0 . 0 0 0 1}$ \\
Heat*Season*Year & $8,43.1$ & 4.62 & $\mathbf{0 . 0 0 0 4}$ \\
Precip*Season*Year & $8,43.1$ & 1.70 & 0.1269 \\
Heat*Precip*Season*Year & $8,43.1$ & 1.41 & 0.2197 \\
\hline Sianifinat & &
\end{tabular}

Significant main effects and interactions are bolded.

interactive treatment effect ( $p=0.0546$ for heat $\times$ precip) on tall fescue abundance was identified (Table 2).

In contrast to our hypothesis that +heat treatments would favor the survival and dominance of $\mathrm{E}+$ individuals over $\mathrm{E}-$ within the tall fescue population, we found relatively limited effects of warming on changes in EIF over time (Table 3, Figure 3).
Table 3 | Statistical results of the effects of the climate treatments (+heat and +precip), month since the project began, and their interactions on the change in tall fescue endophyte infection frequency from the initial harvest June 1, 2009.

\begin{tabular}{lccc}
\hline Effect & Num,Den $\boldsymbol{d f}$ & $\boldsymbol{F}$-value & Pr $>\boldsymbol{F}$ \\
\hline Heat & 1,76 & 1.49 & 0.2260 \\
Precip & 1,76 & 0.06 & 0.8073 \\
Heat* Precip & 1,76 & 0.09 & 0.7713 \\
Month & 4,76 & 3.13 & $\mathbf{0 . 0 1 9 4}$ \\
Heat*Month & 4,76 & 2.31 & 0.0651 \\
Precip*Month & 4,76 & 0.09 & 0.9844 \\
Heat*Precip*Month & 4,76 & 6.49 & $\mathbf{0 . 0 0 0 2}$
\end{tabular}

Bolding indicates significant main effects and interactions.

While a significant heat $\times$ precip $\times$ month since experiment began interaction was found, comparison tests identified only one significant mean separation. In October 2012, tall fescue within the +heat plots tested $20 \%$ more endophyte infected than in the beginning of the project, while the control plot EIF appeared to have not changed. However, this apparent warming effect disappeared the next year, as there were no significant treatment differences identified in October 2013 samples. Differences in EIF across time within a temperature treatment did occur (e.g., for +heat, changes in EIF in October 2012 were greater than in October 2010; for + precip, changes in EIF was greater in October 2012 than in October 2013; and for +heat+precip plots, changes in EIF was greater in October 2011 than in October 2009, 2010, and 2012). 


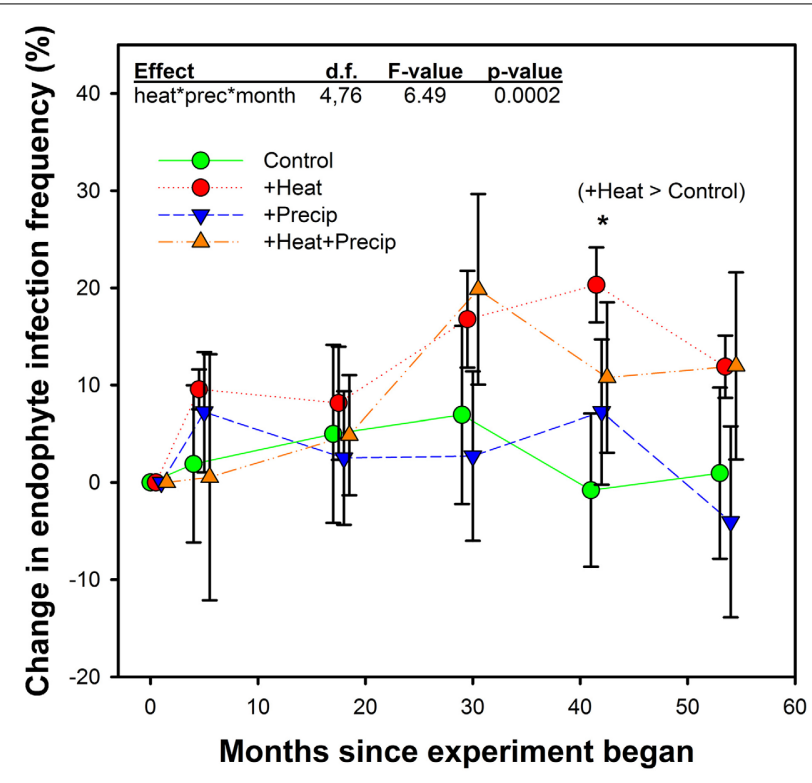

FIGURE 3 | Average ( \pm SE) change in endophyte infection frequency within the tall fescue population in each plot over the 5 years study in heated and non-heated, ambient temperature treatments. Points are slightly offset to clarify presentation, but measurements occurred at the same time for all treatments. Initial endophyte infection frequency averaged $41.1 \%( \pm 3.3)$ across the site. Plot-level initial (June 2009) individual values were set as the zero point in this figure, and change from these values were calculated for measurements which occurred in Octobers from 2009-2013. The highest order significant interaction between heat, precipitation, and month since project began is shown, along with the only significant treatment comparison. See Table 2 for full statistical results. ${ }^{*} p=0.0346$.

\section{ALKALOIDS}

Warming significantly increased concentrations of both measured ergot alkaloids and their sum, but this effect was primarily limited to the Fall harvested material (Figure 4, Table 4). Except for Spring 2013, the last year of the study, no warming effect was observed in Spring harvested material. The Spring 2013 trend was similar to Fall effects: +heat treatments had higher concentrations of ergot alkaloids than the non-heated, ambient temperature treatments. The magnitude of the warming induced increase in ergot alkaloids varied over time from +20.4 to $+74.1 \%$ for ergovaline and +31.6 to $+61.8 \%$ for ergovalinine. For both compounds, warming effects were strongest in Fall 2010, 2011, and 2012.

For the measured loline alkaloids, Fall harvested material tended to have significantly greater concentrations than Spring material (Figure 5, Table 5). The magnitude of difference between the seasons varied across years (hence the significant season $\times$ year interactions) and for the different compounds measured. NFL was the only loline alkaloid that had similar concentrations in Spring and Fall harvested material, and this only occurred in one year-2010. For all three loline compounds, Fall 2012 had the highest measured concentrations.

Fall harvested material was also the only material that exhibited significant climate treatment effects on loline concentrations (Figure 6, Table 5). Across all 5 years of the study, in Fall harvested material, the combination of +heat and + precip produced significantly higher concentrations of all three measured loline compounds and their sum. None of the other three climate treatments (+heat alone, +precip alone, or the ambient control) differed from each other.

\section{DISCUSSION}

Our hypothesis that warming would reduce the relative abundance of tall fescue in this mixed species pasture, in part by increasing summer water limitation, a condition which is known to be stressful for this cool-season, $\mathrm{C}_{3}$ physiology grass (Belesky and West, 2009), was supported. Warming did reduce soil moisture, particularly in the summer and fall, and in every year of the study, warmed plots had significantly less tall fescue than ambient temperature plots. However, water limitation is only one potential factor explaining the warming associated decline in tall fescue abundance: competition from other plant species was most likely also important. Indeed, the increase in tall fescue abundance that was observed at the start of the second growing season (2010) across all treatments was associated with a dramatic decline in red clover, which was the dominant species in all treatments at the start of the project (data not shown). Additionally, in every year of the project, as seasonal temperatures increased from spring to summer and fall, warm-season, $\mathrm{C}_{4}$ physiology grasses (initially crabgrass, Digitaria spp., which recruited naturally from the seed bank, and later on in the project, Bermuda, which was planted) increased in dominance. These species were most abundant in the warmed treatments (data not shown) and were most likely strong competitors with tall fescue. Given the stressful conditions (both abiotic and biotic) that warming created for tall fescue, it is remarkable that it persisted in these plots for the duration of the study, at relatively stable levels.

One hypothesis that might explain how tall fescue managed to persist and effectively compete in the stressful warmed conditions of our project is that competitively superior, more environmental stress tolerant, E+ individuals were being selected for over time in these treatments, as $\mathrm{E}-$ individuals perished. However, this is not what we observed. Only at one point in time in our study, October 2012, after 4 years of experimental conditions, did we identify a significant treatment effect on the change in EIF over time. This effect was in the direction of what we hypothesized (the +heat treatment had 20\% more E+ individuals than at the start of the experiment, whereas the EIF in the control treatment had not changed), but the significance of the effect disappeared the following year. In general, changes in EIF over time tended to be positive for theat and +heat+precip treatments but were relatively small in magnitude (averaging $11.5 \%$ increase over time), while + precip and control treatments averaged almost no change (3.0\% increase). The lack of a substantial change in EIF over time observed in this study, despite warming increasing abiotic and biotic stress, concurs with the results of Brosi et al. (2011b), who found that neither warming $\left(+3^{\circ} \mathrm{C}\right)$ nor water limitation caused significant change in tall fescue EIF in a constructed, multi-species old field in Tennessee.

These results suggest that the importance of endophyte infection to tall fescue's ability to withstand and recover from elevated temperatures and water-limiting conditions may be less 


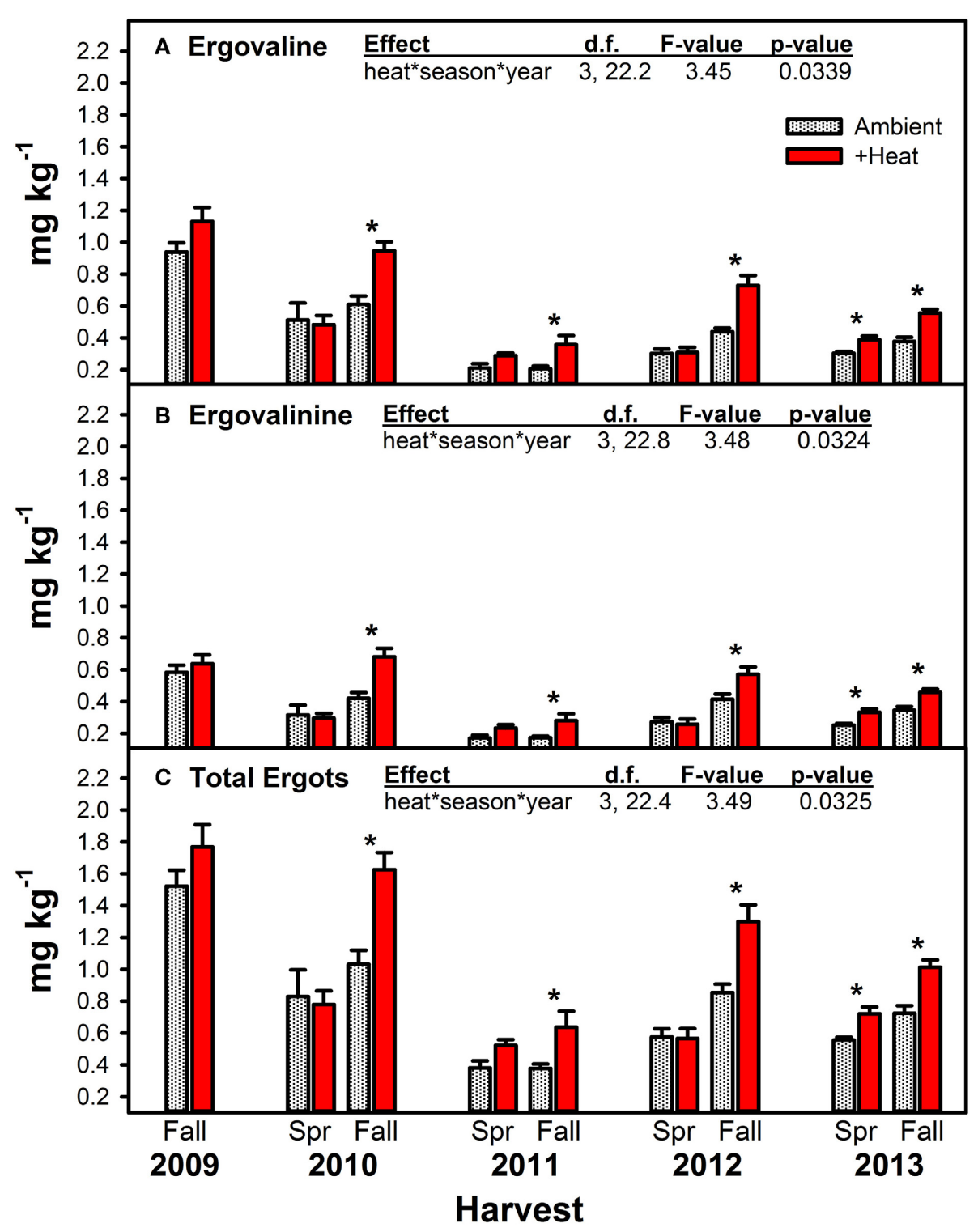

FIGURE 4 | Average ( \pm SE) concentrations of ergovaline (A), ergovalinine (B), and the sum of these two ergot alkaloids (C) measured in endophyte-infected tall fescue tillers harvested from heated and non-heated, ambient temperature treatments in Spring and Fall of all years of the study. Spring 2009 is missing due to lab error. The highest order significant interaction between heat, season, and year is shown (see Table 4 for full statistical results). Harvest periods with significant differences between treatments are indicated with an "*." than prior work suggests. It is possible that our experimental treatments were not harsh enough to evoke the symbiotic benefits; however, both 2010 and 2012 were drier than normal years, with 2012 having one of the driest early growing seasons on record at the site (Mallya et al., 2013). Therefore, it is difficult to believe that the +heat treatment would not have produced harsh conditions for tall fescue at least at that time. These environmental conditions may have played into the Fall of 2012 being the only time period when significant treatment differences in the change in EIF over time were identified. It is also possible that endophyte benefits are conferred under more intense, but shorter duration, abiotic "extreme" events_-rather than the long, continuous nature of our experimental climate manipulations. Additional work could further explore these possibilities.

Our results of relatively limited importance of endophyte infection to tall fescue abiotic stress tolerance are not unheard of: not all studies have shown benefits of endophyte infection to tall fescue under stressful conditions (MacLean et al., 1993; Richardson et al., 1993; Elbersen and West, 1996; Buck et al., 1997). Some have shown no effects (Arachevaleta et al., 1989; Belesky et al., 1989; Hill et al., 1996), and work performed in this same project found that $\mathrm{E}+$ tall fescue experienced more mortality than E- after 1 month of theat treatments (Brosi, 2011a) and that tall fescue's response to the treatments is under plant genetic control, in addition to being impacted by Epichloë 
Table 4 | Statistical results of the effects of the climate treatments (+heat and +precip), season, year, and their interactions on the concentrations of ergovaline, ergovalinine, and their sum (total ergots measured in this study) in endophyte infected tall fescue tillers.

\begin{tabular}{|c|c|c|c|c|c|c|c|c|c|}
\hline \multirow[t]{3}{*}{ Effect } & \multicolumn{3}{|c|}{ Ergovaline } & \multicolumn{3}{|c|}{ Ergovalinine } & \multicolumn{3}{|c|}{ Total ergots } \\
\hline & \multirow{2}{*}{$\frac{\text { Num,Den }}{d f}$} & \multirow[b]{2}{*}{$F$-value } & \multirow[b]{2}{*}{$\operatorname{Pr}>\boldsymbol{F}$} & \multirow{2}{*}{$\frac{\text { Num,Den }}{d f}$} & \multirow[b]{2}{*}{$F$-value } & \multirow[b]{2}{*}{$\operatorname{Pr}>\boldsymbol{F}$} & \multirow{2}{*}{$\frac{\text { Num,Den }}{d f}$} & \multirow[b]{2}{*}{$F$-value } & \multirow[b]{2}{*}{$\operatorname{Pr}>\boldsymbol{F}$} \\
\hline & & & & & & & & & \\
\hline Heat & $1,17.2$ & 20.9 & 0.0003 & $1,26.2$ & 13.66 & 0.0010 & $1,20.5$ & 18.67 & 0.0003 \\
\hline Precip & $1,17.2$ & 0.84 & 0.3727 & $1,26.2$ & 0.40 & 0.5302 & $1,20.5$ & 0.68 & 0.4207 \\
\hline Heat*Precip & $1,17.2$ & 1.60 & 0.2226 & $1,26.2$ & 1.07 & 0.3095 & $1,20.5$ & 1.45 & 0.2427 \\
\hline Season & $1,20.4$ & 57.14 & $<0.0001$ & $1,20.0$ & 67.68 & $<0.0001$ & $1,20.2$ & 65.08 & $<0.0001$ \\
\hline Heat*Season & $1,20.4$ & 18.89 & 0.0003 & $1,20.0$ & 12.94 & 0.0018 & $1,20.2$ & 17.07 & 0.0005 \\
\hline Precip*Season & $1,20.4$ & 0.00 & 0.9807 & $1,20.0$ & 0.08 & 0.7788 & $1,20.2$ & 0.02 & 0.8911 \\
\hline Heat*Precip*Season & $1,20.4$ & 0.01 & 0.9062 & $1,20.0$ & 0.03 & 0.8720 & $1,20.2$ & 0 & 0.9940 \\
\hline Year & $4,17.4$ & 35.83 & $<0.0001$ & $4,18.1$ & 22.3 & $<0.0001$ & $4,17.5$ & 30.65 & $<0.0001$ \\
\hline Heat*Year & $4,17.4$ & 0.21 & 0.9319 & $4,18.1$ & 0.80 & 0.5382 & $4,17.5$ & 0.32 & 0.8638 \\
\hline Precip* Year & $4,17.4$ & 0.65 & 0.6368 & $4,18.1$ & 0.42 & 0.7937 & $4,17.5$ & 0.56 & 0.6951 \\
\hline Heat*Precip*Year & $4,17.4$ & 1.37 & 0.2858 & $4,18.1$ & 0.78 & 0.5532 & $4,17.5$ & 1.12 & 0.3801 \\
\hline Season*Year & $3,22.2$ & 10.24 & 0.0002 & $3,22.8$ & 11.36 & $<0.0001$ & $3,22.4$ & 10.93 & 0.0001 \\
\hline Heat* Season*Year & $3,22.2$ & 3.45 & 0.0339 & $3,22.8$ & 3.48 & 0.0324 & $3,22.4$ & 3.49 & 0.0325 \\
\hline Precip*Season*Year & $3,22.2$ & 0.56 & 0.6465 & $3,22.8$ & 0.80 & 0.5087 & $3,22.4$ & 0.59 & 0.6228 \\
\hline Heat*Precip*Season*Year & $3,22.2$ & 0.64 & 0.5951 & $3,22.8$ & 0.05 & 0.9843 & $3,22.4$ & 0.29 & 0.8338 \\
\hline
\end{tabular}

Bolding indicates significant main effects and interactions.

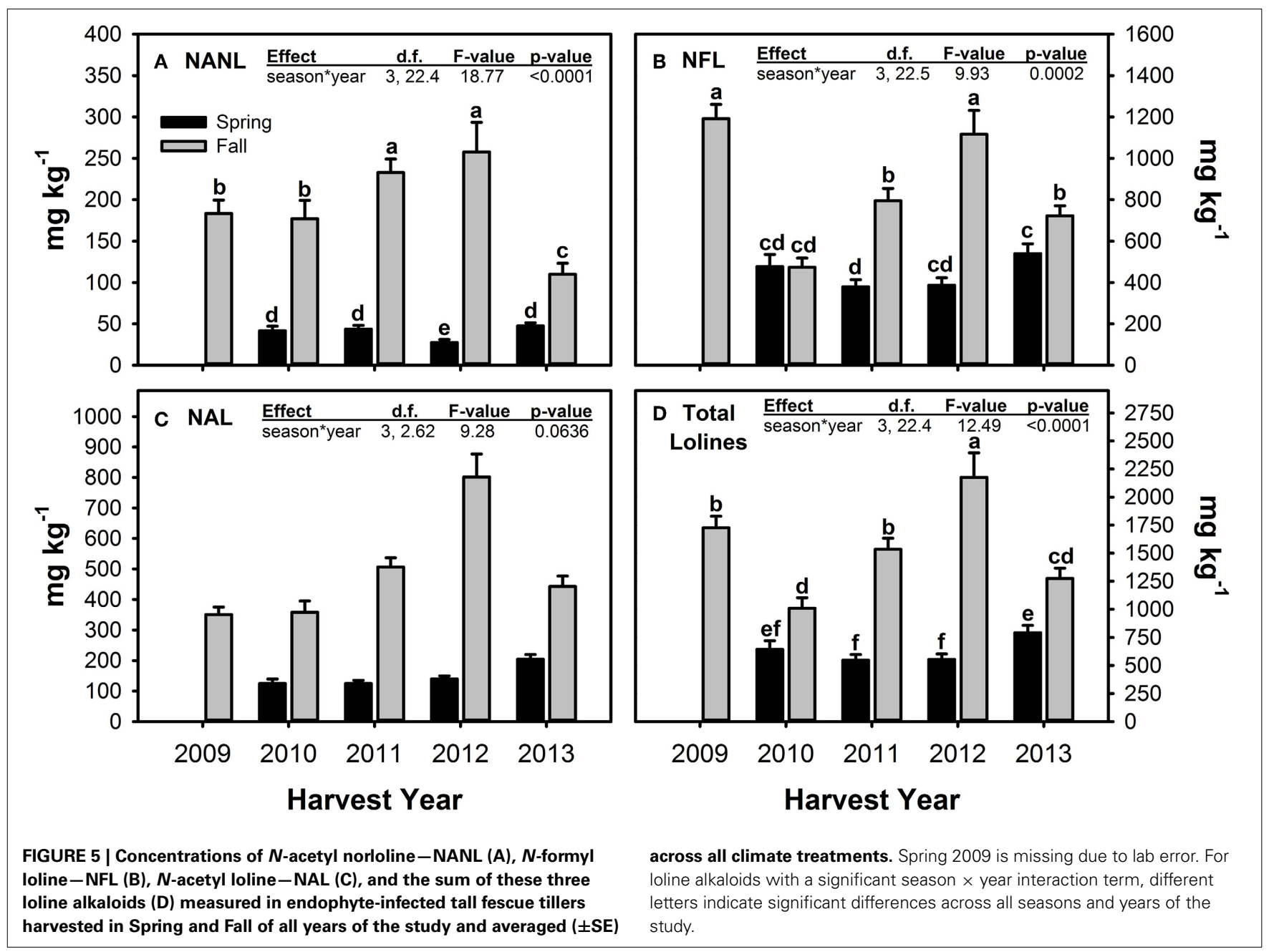




\begin{tabular}{|c|c|c|c|c|c|c|c|c|c|c|c|c|}
\hline \multirow{2}{*}{ Effect } & \multicolumn{3}{|c|}{ NANL } & \multicolumn{3}{|c|}{ NFL } & \multicolumn{3}{|c|}{ NAL } & \multicolumn{3}{|c|}{ Total Iolines } \\
\hline & $d f$ & $F$-value & $\operatorname{Pr}>F$ & $d f$ & $F$-value & $\operatorname{Pr}>F$ & $d f$ & $F$-value & $\operatorname{Pr}>F$ & $d f$ & $F$-value & $\operatorname{Pr}>F$ \\
\hline Heat & $1,21.5$ & 18.51 & 0.0003 & $1,17.3$ & 6.94 & 0.0173 & $1,8.75$ & 16.85 & 0.0028 & $1,20.9$ & 16.01 & 0.0007 \\
\hline Heat*Prec & $1,21.5$ & 2.77 & 0.1107 & $1,17.3$ & 1.53 & 0.2322 & $1,8.75$ & 5.55 & 0.0436 & $1,20.9$ & 3.91 & 0.0614 \\
\hline Seas & $1,22.7$ & 175.47 & $<0.0001$ & $1,22.6$ & 90.85 & $<0.0001$ & $1,2.13$ & 397.27 & 0.0018 & $1,22.9$ & 223.34 & $<0.0001$ \\
\hline Heat*Seas & $1,22.7$ & 11.58 & 0.0025 & $1,22.6$ & 3.64 & 0.0691 & $1,2.13$ & 12.90 & 0.0632 & $1,22.9$ & 9.07 & 0.0062 \\
\hline Prec*Seas & $1,22.7$ & 2.34 & 0.1403 & $1,22.6$ & 10.45 & 0.0037 & $1,2.13$ & 4.84 & 0.1510 & $1,22.9$ & 8.84 & 0.0068 \\
\hline Heat*Prec*Seas & $1,22.7$ & 6.40 & 0.0188 & $1,22.6$ & 16.78 & 0.0005 & $1,2.13$ & 19.42 & 0.0425 & $1,22.9$ & 19.53 & 0.0002 \\
\hline Yr & $4,17.5$ & 8.94 & 0.0004 & $4,17.6$ & 14.71 & $<0.0001$ & $4,3.34$ & 8.18 & 0.0474 & $4,16.9$ & 7.07 & 0.0016 \\
\hline Seas*Yr & $3,22.4$ & 18.77 & $<0.0001$ & $3,22.5$ & 9.93 & 0.0002 & $3,2.62$ & 9.28 & 0.0636 & $3,22.4$ & 12.49 & $<0.0001$ \\
\hline Heat*Seas*Yr & $3,22.4$ & 1.39 & 0.2708 & $3,22.5$ & 1.74 & 0.1875 & $3,2.62$ & 2.21 & 0.2843 & $3,22.4$ & 1.97 & 0.1472 \\
\hline Prec*Seas*Yr & $3,22.4$ & 1.36 & 0.2806 & $3,22.5$ & 0.07 & 0.9747 & $3,2.62$ & 0.08 & 0.9635 & $3,22.4$ & 0.11 & 0.9550 \\
\hline Heat*Prec*Seas* ${ }^{*} r$ & $3,22.4$ & 1.19 & 0.3369 & $3,22.5$ & 0.10 & 0.9596 & $3,2.62$ & 0.38 & 0.7769 & $3,22.4$ & 0.22 & 0.8798 \\
\hline
\end{tabular}

Bolding indicates significant main effects and interactions.

presence and strain type (Bourguignon, 2013). We did not control for plant genetic background in this experiment, as we were interested in measuring changes to the population, and it is possible that differing fescue genotypes in our project responded to both climate treatments and endophyte presence in contrasting ways (West, 2007), which might have hampered our ability to detect an endophyte-associated response to the climate treatments. Complicated symbiotic responses to abiotic perturbations and their resulting effects on various ecological parameters are consistent with the growing body of knowledge regarding controls of grass-Epichloë interactions (Faeth and Saikkonen, 2007; West, 2007; Rudgers et al., 2010; Yurkonis et al., 2014), and will need to be factored into predictions regarding population-level grass symbiotic responses to climate change.

It is possible that the primary importance of the fungal endophyte symbiosis for tall fescue under altered climatic conditions will be conferred through interactions with herbivory. Field manipulations of herbivory have clearly demonstrated that endophyte presence confers an advantage under high herbivore pressure, such that significant increases in EIF of the tall fescue community were observed over time (Clay et al., 2005). In our project, in $\mathrm{E}+$ individuals, we measured significant increases in both ergot and loline alkaloids in fall plant material from treatments representative of predicted future climates for the region. Because these compounds are toxic to herbivores, these results suggest that those herbivores capable of selecting for E- fescue or utilizing other plant species will do so, potentially altering plant competitive dynamics.

While assessing the response of herbivores to the climate change treatments was not the primary focus of our study, concurrent projects that monitored aphids, slugs, and small mammal seed predation and population dynamics, at varying times throughout the 5 years project, found few changes in herbivore numbers or feeding patterns related to the biotic and abiotic alterations that the climate change treatments produced. Rua et al. (2014) monitored aphids in May 2010 and found that there were more aphids in the +heat plots than the other treatments, but was unable to test for differences in aphid numbers between $\mathrm{E}+$ and $\mathrm{E}-$ tall fescue due to low numbers of aphids being found on this material-a result similar to that of Brosi (2011a). Three years of slug manipulations and trapping at the site indicated that slug herbivory levels were low and that climate treatment effects on these herbivores were minor (Weber, 2014). Small mammal, primarily vole (Microtus pennsylvanicus, M. ochrogaster), population dynamics varied from year-to-year, as is common for these organisms (Chitty, 1960; Krebs and Myers, 1974), but seed predation was generally similar across plots (A.E. Carlisle, unpublished data). It is possible that the mowing regime or other environmental or site factors created conditions that minimized herbivory levels at our site, and may be one reason why changes in EIF were not observed, despite climate treatments increasing alkaloid concentrations and significantly altering the abiotic environment and plant communities. Changes in tall fescue EIF may have been more dramatic had selective, heavy grazing, rather than non-selective mowing, been practiced on site, though it should be noted that an experiment in southern Illinois found that mowing increased water limitation, which the authors hypothesized selected for higher EIF of the tall fescue in mowed compared to adjacent not mowed plots (Spyreas et al., 2001). The factors causing the observed lack of change in EIF in this experiment remain unknown.

Our project failed to incorporate increases in atmospheric $\mathrm{CO}_{2}$ concentrations, due to financial and infrastructure limitations, 


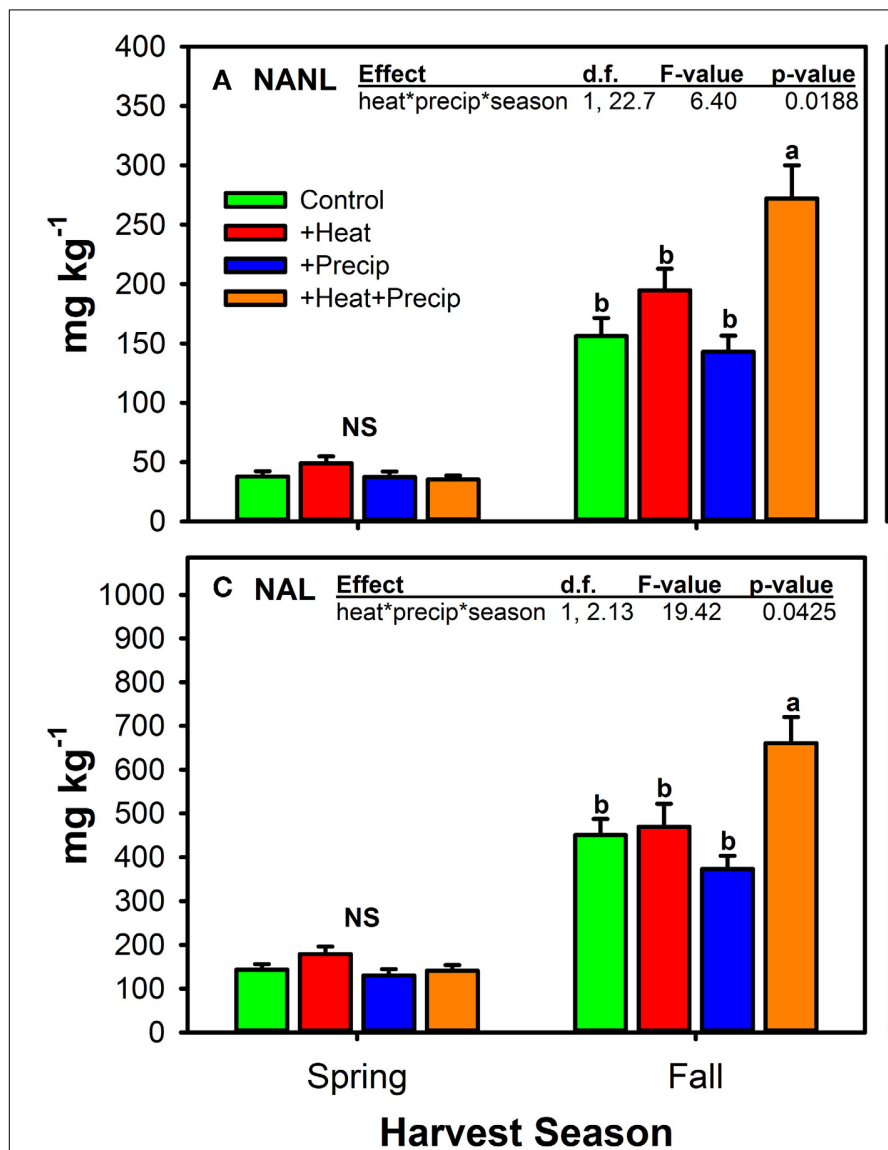

FIGURE 6 | Concentrations of $\boldsymbol{N}$-acetyl norloline-NANL (A), $\boldsymbol{N}$-formyl loline-NFL (B), N-acetyl loline-NAL (C), and the sum of these three loline alkaloids (D) measured in endophyte-infected tall fescue tillers from each of the four climate treatments averaged ( \pm SE) by season of harvest (Spring or Fall) and across years of the study. The highest order

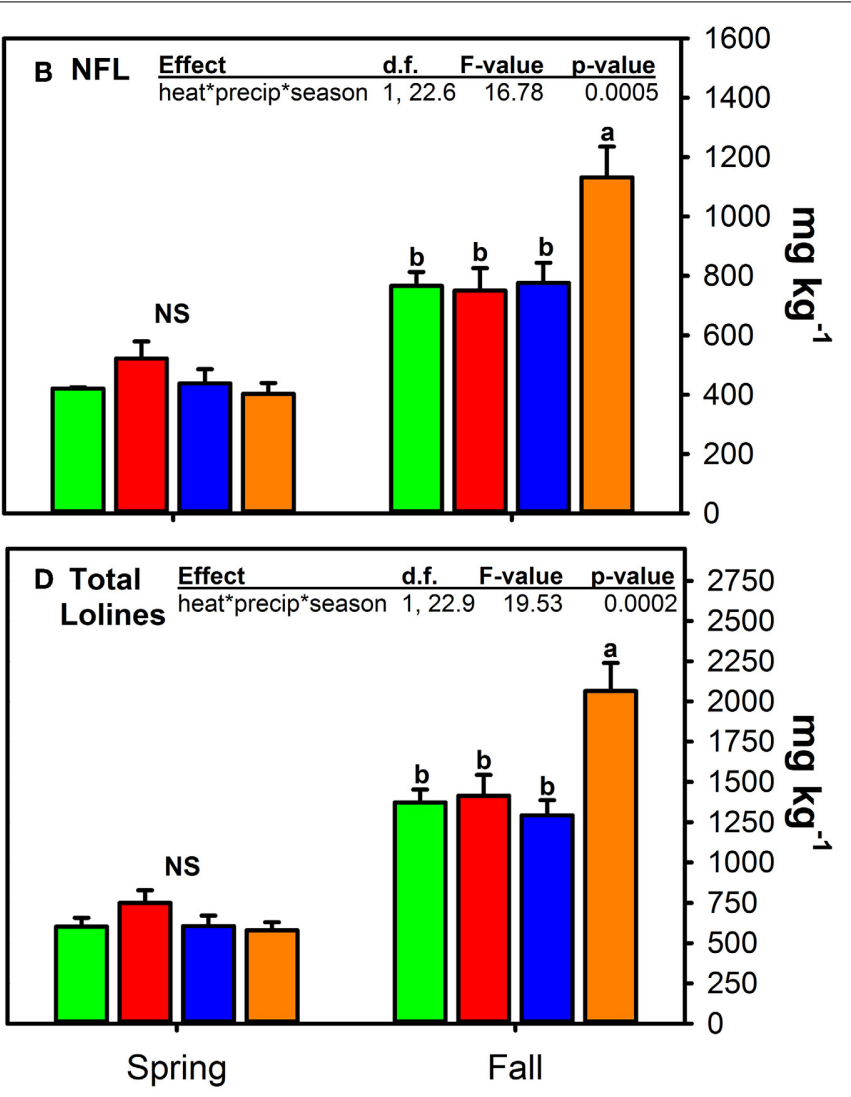

Harvest Season

significant interaction between heat, precip, and season is shown (see Table 5 for full statistical results). NS indicates seasons when there were no statistically significant differences between the climate treatments. Otherwise, different letters illustrate significant differences between climate treatments. which is unfortunate as this factor will be an important component of future environmental conditions and may modify effects of warming and altered precipitation on tall fescue (Yu et al., 2012), and has been shown to be important in governing the fescue-endophyte symbiosis. Brosi et al. (2011b) found that elevated $\mathrm{CO}_{2}$ increased the occurrence of $\mathrm{E}+$ tall fescue individuals in a mixed species stand but reduced the concentrations of both ergot and loline alkaloids. Ryan et al. (2014) also reported reduced alkaloid concentrations in $\mathrm{E}+$ tall fescue in response to elevated $\mathrm{CO}_{2}$, despite measuring increased fungal DNA concentrations in these same individuals. In contrast to the Brosi et al. (2011b) work, we measured significant increases in ergot alkaloids in response to warming (Brosi measured no response of ergots to warming), and we found that lolines increased in concentration only when warming was accompanied by additional precipitation (Brosi found warming alone stimulated lolines, that dry, not wet conditions, increased loline concentrations, and there was no interaction between warming and water availability in that study). Differences in site conditions or experimental designs and treatments may account for these discrepancies, as nitrogen availability has been shown to alter the response of alkaloid concentrations to elevated $\mathrm{CO}_{2}$ in perennial ryegrass when infected with E. festucae var. lolii (Hunt et al., 2005).

Clearly, the Epichloë-tall fescue symbiosis will be affected by and respond to climate change factors. Given that all research performed to date on the subject has shown alkaloids to be responsive to the effects of elevated atmospheric $\mathrm{CO}_{2}$, warming, and drought/additional precipitation, and these biological compounds play key roles in governing herbivory and animal production in pastures, it is imperative that future work attempts to better characterize the interactive effects of these various climate change factors on alkaloid concentrations. Brosi et al. (2011b) is the only paper to date able to assess the interactive effects, and they found no significant interactions on any of the measured compounds, suggesting that the individual climate treatment main effects cancel each other out. However, replication was limited in the Brosi work $(n=3)$, and the above-mentioned differences between our results and theirs for warming and precipitation manipulations suggest that additional factors may be governing tall fescue-endophyte alkaloid responses. If elevated atmospheric $\mathrm{CO}_{2}$ does not mitigate the effects of warming and changes in precipitation on alkaloid concentrations in $\mathrm{E}+$ tall 
fescue, our data suggest that those herbivores that are incapable of altering forage selection (e.g., cattle grazing highly infected tall fescue dominated pastures) will likely consume higher levels of these toxic compounds, and they will do so at an already hot time of the year in many places (late Summer/Fall), when there are significant challenges to maintaining ideal thermal conditions for optimal animal functioning (Spiers et al., 2005). Additional research evaluating pasture management options to reduce consumption of toxic alkaloids (e.g., the use of novel, non-toxic endophyte infected material, specific grazing strategies, and/or other forage species, especially warm season grasses; Aiken and Strickland, 2013) while sustaining pasturebased animal production under future climatic conditions seems warranted.

\section{AUTHOR CONTRIBUTIONS}

Rebecca L. McCulley and Jim A. Nelson conceived the research idea and designed the experiment. All authors were involved in aspects of data acquisition, analysis, and interpretation. All authors contributed to writing the manuscript, approved the final version, and are accountable for the data presented and interpretation therein.

\section{ACKNOWLEDGMENTS}

This work was supported by a grant to Rebecca L. McCulley (US Department of Energy 08-SC-NICCR-1073), a cooperative agreement with the USDA-ARS Forage Animal Production Research Unit (58-6440-7-135), the Kentucky Agricultural Experiment Station (KY006045), and the University of Kentucky's College of Agriculture, Food, and the Environment. The following people deserve thanks for the hours of time they contributed to the planting, harvesting, sorting, grinding, and blotting required: Maria Almagro, Sara Arthur-Paratley, Marie Bourguignon, Luke Box, Alexis Breton, Glade Brosi, Cody Burton, Allison Cooke, Dawn DeColibus, Jarred Earnest, Amael Gy, Sarah Hall, Javed Iqbal, Eric Kalosa-Kenyon, Ben Leffew, Marléne Mauras, Michael Payton May, Lindsey Slaughter, Rachel Smith, and Dan Weber. We also thank Kristen McQuerry and the UK Department of Statistics for statistical analysis assistance.

\section{REFERENCES}

Agee, C. S., and Hill, N. S. (1994). Ergovaline variability in acremonium-infected tall fescue due to environment and plant genotype. Crop Sci. 34, 221-226. doi: 10.2135/cropsci1994.0011183X003400010040x

Aiken, G. E., and Strickland, J. R. (2013). Forages and pasture management symposium: managing the tall fescue-fungal endophyte symbiosis for optimum forage-animal production. J. Anim. Sci. 91, 2369-2378. doi: 10.2527/jas.20125948

Arachevaleta, M., Bacon, C. W., Hoveland, C. S., and Radcliffe, D. E. (1989). Effect of the tall fescue endophyte on plant-response to environmental-stress. Agron. J. 81, 83-90. doi: 10.2134/agronj1989.00021962008100010015x

Arnold, A. E., Maynard, Z., Gilbert, G. S., Coley, P. D., and Kursar, T. A. (2000). Are tropical fungal endophytes hyperdiverse? Ecol. Lett. 3, 267-274. doi: 10.1046/j.1461-0248.2000.00159.x

Assuero, S. G., Tognetti, J. A., Colabelli, M. R., Agnusdei, M. G., Petroni, E. C., and Posse, M. A. (2006). Endophyte infection accelerates morpho-physiological responses to water deficit in tall fescue. New Zeal. J. Agr. Res. 49, 359-370. doi: 10.1080/00288233.2006.9513726

Backlund, P., Schimel, D., Janetos, A., Hatfield, J., Ryan, M., Archer, S., et al. (2008). Introduction: the Effects of Climate Change on Agriculture, Land Resources, Water
Resources, and Biodiversity. Washington, DC: U.S. Climate Change Science Program and the Subcommittee on Global Change Research.

Ball, D. M., Pedersen, J. F., and Lacefield, G. D. (1993). The tall-fescue endophyte. Am. Sci. 81, 370-379.

Belesky, D. P., Stringer, W. C., and Hill, N. S. (1989). Influence of endophyte and water regime upon tall fescue accessions. 1. Growth-characteristics. Ann. Bot. 63, 495-503.

Belesky, D. P., and West, C. P. (2009). Abiotic stresses and endophyte effects. Tall fescue for the twenty-first century. Agron. Monogr. 53, 49-64. doi: 10.2134/agronmonogr53.c4

Blankenship, J. D., Spiering, M. J., Wilkinson, H. H., Fannin, F. F., Bush, L. P., and Schardl, C. L. (2001). Production of loline alkaloids by the grass endophyte, Neotyphodium uncinatum, in defined media. Phytochemistry 58, 395-401. doi: 10.1016/S0031-9422(01)00272-2

Bourguignon, M. (2013). Ecophysiological Responses of tall Fescue Genotypes to Endophyte Infection and Climate Change. Theses and Dissertations, Plant and Soil Sciences, University of Kentucky. Paper 28. Available online at: http://uknowledge.uky.edu/pss_etds/28.

Bouton, J. H., Gates, R. N., Belesky, D. P., and Owsley, M. (1993). Yield and persistence of tall fescue in the southeastern coastal-plain after removal of its endophyte. Agron. J. 85, 52-55. doi: 10.2134/agronj1993.0002196200850001 $0011 x$

Brosi, G. B. (2011a). The Response of Tall Fescue and its Fungal Endophyte to Climate Change. Theses and Dissertations, Plant and Soil Sciences, University of Kentucky. Paper 126. Available online at: http://uknowledge.uky.edu/gradschool_theses/126

Brosi, G. B., McCulley, R. L., Bush, L. P., Nelson, J. A., Classen, A. T., and Norby, R. J. (2011b). Effects of multiple climate change factors on the tall fescue-fungal endophyte symbiosis: infection frequency and tissue chemistry. New Phytol. 189, 797-805. doi: 10.1111/j.1469-8137.2010.03532.x

Brunjes, J. (2004). Action Plan to Respond to Climate Change in Kentucky: a Strategy of Resilience. Frankfort, KY: Kentucky Department of Fish and Wildlife.

Buck, G. W., West, C. P., and Elbersen, H. W. (1997). "Endophyte effect on drought tolerance in diverse Festuca species," in Neotyphodium/Grass Interactions, eds C. W. Bacon and N. S Hill (NewYork, NY: Plenum Press), 141-143.

Bush, L. P., Wilkinson, H. H., and Schardl, C. L. (1997). Bioprotective alkaloids of grass-fungal endophyte symbioses. Plant Physiol. 114, 1-7.

Chen, X., Tu, C., Burton, M. G., Watson, D. M., Burkey, K. O., and Hu, S. (2007). Plant nitrogen acquisition and interactions under elevated carbon dioxide: impact of endophyte and mycorrhizae. Glob. Change Biol. 13, 1238-1249. doi: 10.1111/j.1365-2486.2007.01347.x

Cheplick, G. P., and Faeth, S. H. (2009). Ecology and Evolution of the GrassEndophyte Symbiosis. New York, NY: Oxford University Press.

Chitty, D. (1960). Population processes in the vole and their relevance to general theory. Can. J. Zool. 38, 99-113. doi: 10.1139/z60-011

Clay, K. (1990). Fungal endophytes of grasses. Annu. Rev. Ecol. Evol. Syst. 21, 275-297. doi: 10.1146/annurev.es.21.110190.001423

Clay, K., and Holah, J. (1999). Fungal endophyte symbiosis and plant diversity in successional fields. Science 285, 1742-1744. doi: 10.1126/science.285.5434.1742

Clay, K., Holah, J., and Rudgers, J. A. (2005). Herbivores cause a rapid increase in hereditary symbiosis and alter plant community composition. Proc. Natl. Acad. Sci. U.S.A. 102, 12465-12470. doi: 10.1073/pnas.05030 59102

Clay, K., and Schardl, C. (2002). Evolutionary origins and ecological consequences of endophyte symbiosis with grasses. Am. Nat. 160, S99-S127. doi: $10.1086 / 342161$

Compant, S., Van Der Heijden, M. G. A., and Sessitsch, A. (2010). Climate change effects on beneficial plant-microorganism interactions. FEMS Microbiol. Ecol. 73, 197-214. doi: 10.1111/j.1574-6941.2010.00900.x

Elbersen, H. W., and West, C. P. (1996). Growth and water relations of fieldgrown tall fescue as influenced by drought and endophyte. Grass Forage Sci. 51, 333-342. doi: 10.1111/j.1365-2494.1996.tb02068.x

Elmi, A., and West, C. (1995). Endophyte infection effects on stomatal conductance, osmotic adjustment and drought recovery of tall fescue. New Phytol. 131, 61-67. doi: 10.1111/j.1469-8137.1995.tb03055.x

Faeth, S. H., and Saikkonen, K. (2007). "Variability is the nature of the endophytegrass interaction," in Proceedings of the 6th International Symposium on Fungal Endophytes of Grasses, eds A. J. Popay and E. R. Thom (Christchurch: New Zealand Grassland Association (no. 13)), 37-48. 
Ferreira, W. P. M., Priddy, T. K., Souza, C. F., and Mathews, J. (2010). "Trends in precipitation and air temperature time series in Lexington/KY - USA," in ASABE Annual International Meeting. Paper \# 1009768 (Pittsburgh, PA), 3-13.

Hiatt, E., Hill, N., Bouton, J., and Stuedemann, J. (1999). Tall fescue endophyte detection: commercial immunoblot test kit compared with microscopic analysis. Crop Sci. 39, 796-799.

Hill, N., Pachon, J., and Bacon, C. (1996). Acremonium coenophialum-mediated short-and long-term drought acclimation in tall fescue. Crop Sci. 36, 665-672. doi: 10.2135/cropsci1996.0011183X003600030025x

Hoveland, C. S. (1993). Importance and economic significance of the Acremonium endophytes to performance of animals and grass plant. Agr. Ecosyst. Environ. 44, 3-12. doi: 10.1016/0167-8809(93)90036-O

Hoveland, C. S. (2009). Origin and history. Tall fescue for the twenty-first century. Agron. Monogr. 53, 3-10. doi: 10.2134/agronmonogr53.c1

Hunt, M. G., Rasmussen, S., Newton, P. C. D., Parsons, A. J., and Newman, J. A. (2005). Near-term impacts of elevated CO2, nitrogen and fungal endophyte-infection on Lolium perenne L. growth, chemical composition and alkaloid production. Plant Cell Environ. 28, 1345-1354. doi: 10.1111/j.13653040.2005.01367.x

Ju, H. J., Hill, N. S., Abbott, T., and Ingram, K. T. (2006). Temperature influences on endophyte growth in tall fescue. Crop Sci. 46, 404-412. doi: 10.2135/cropsci2005.0282

Karl, T. R., Melillo, J. M., and Peterson, T. C. (2009). Global Climate Change Impacts in the United States. New York, NY: Cambridge University Press.

Kimball, B. A., Conley, M. M., Wang, S., Lin, X., Luo, C., Morgan, J., et al. (2008). Infrared heater arrays for warming ecosystem field plots. Glob. Change Biol. 14, 309-320. doi: 10.1111/j.1365-2486.2007.01486.x

Kivlin, S. N., Emery, S. M., and Rudgers, J. A. (2013). Fungal symbionts alter plant responses to global change. Am. J. Bot. 100, 1445-1457. doi: 10.3732/ajb. 1200558

Krebs, C. J., and Myers, J. H. (1974). Population cycles in small mammals. Adv. Ecol. Res. 8, 267-399. doi: 10.1016/S0065-2504(08)60280-9

Leuchtmann, A., Bacon, C. W., Schardl, C. L., White, J. F., and Tadych, M. (2014). Nomenclatural realignment of Neotyphodium species with genus Epichloë. Mycologia 106, 202-215. doi: 10.3852/106.2.202

Leuchtmann, A. (1992). Systematics, distribution, and host specificity of grass endophytes. Nat. Toxins 1, 150-162. doi: 10.1002/nt.2620010303

Lewis, G. C., Ravel, C., Naffaa, W., Astier, C., and Charmet, G. (1997). Occurrence of Acremonium endophytes in wild populations of Lolium spp. in European countries and a relationship between level of infection and climate in France. Ann. Appl. Biol. 130, 227-238. doi: 10.1111/j.1744-7348.1997.tb06828.x

MacLean, B., Matthew, C., Latch, G., and Barker, D. (1993). "The effect of endophyte on drought resistance in tall fescue," in Proceedings of the Second International Symposium on Acremonium/Grass Interactions, eds D. E. Hume, G. C. M. Latch, and H. S. Easton (Palmerston North: AgResearch), 165-169.

Malinowski, D. P., and Belesky, D. P. (2000). Adaptations of endophyte-infected cool-season grasses to environmental stresses: mechanisms of drought and mineral stress tolerance. Crop Sci. 40, 923-940. doi: 10.2135/cropsci2000.404923x

Mallya, G., Zhao, L., Song, X., Niyogi, D., and Govindaraju, R. (2013). 2012 Midwest drought in the United States. J. Hydrol. Eng. 18, 737-745. doi: 10.1061/(ASCE)HE.1943-5584.0000786

Marks, S., and Clay, K. (1996). Physiological responses of Festuca arundinacea to fungal endophyte infection. New Phytol. 133, 727-733. doi: 10.1111/j.14698137.1996.tb01941.x

Newman, J. A., Abner, M. L., Dado, R. G., Gibson, D. J., Brookings, A., and Parsons, A. J. (2003). Effects of elevated $\mathrm{CO}_{2}$, nitrogen and fungal endophyte-infection on tall fescue: growth, photosynthesis, chemical composition and digestibility. Glob. Change Biol. 9, 425-437. doi: 10.1046/j.1365-2486.2003.00601.x

Rahman, M., and Saiga, S. (2005). Endophytic fungi (Neotyphodium coenophialum) affect the growth and mineral uptake, transport and efficiency ratios in tall fescue (Festuca arundinacea). Plant Soil 272, 163-171. doi: 10.1007/s11104-0044682-6

Redman, R. S., Kim, Y. O., Woodward, C., Greer, C., Espino, L., Doty, S. L., et al. (2011). Increased fitness of rice plants to abiotic stress via habitat adapted symbiosis: a strategy for mitigating impacts of climate change. PLOS ONE 6:e14823. doi: 10.1371/journal.pone.0014823

Richardson, M. D., Hoveland, C. S., and Bacon, C. W. (1993). Photosynthesis and stomatal conductance of symbiotic and nonsymbiotic tall fescue. Crop Sci. 33, 145-149. doi: 10.2135/cropsci1993.0011183X003300010026x
Roberts, C. A., Lacefield, G. D., Ball, D., and Bates, G. (2009). Management to optimize grazing performance in the northern hemisphere. Tall fescue for the twenty-first century. Agron. Monogr. 53, 85-99. doi: 10.2134/agronmonogr53.c6

Rua, M. A., McCulley, R. L., and Mitchell, C. E. (2014). Climate drivers, host identity and fungal endophyte infection determine virus prevalence in a grassland ecosystem. J. Ecol. 102, 690-699. doi: 10.1111/1365-2745.12238

Rudgers, J. A., Fischer, S., and Clay, K. (2010). Managing plant symbiosis: fungal endophyte genotype alters plant community composition. J. Appl. Ecol. 47, 468-477. doi: 10.1111/j.1365-2664.2010.01788.x

Ryan, G. D., Rasmussen, S., Xue, H., Parsons, A. J., and Newman, J. A. (2014). Metabolite analysis of the effects of elevated $\mathrm{CO}_{2}$ and nitrogen fertilization on the association between tall fescue (Schedonorus arundinaceus) and its fungal symbiont Neotyphodium coenophialum. Plant Cell Environ. 37, 204-212. doi: $10.1111 /$ pce. 12146

Saikkonen, K., Faeth, S., Helander, M., and Sullivan, T. (1998). Fungal endophytes: a continuum of interactions with host plants. Ann. Rev. Ecol. Evol. Syst. 29, 319-343. doi: 10.1146/annurev.ecolsys.29.1.319

Schardl, C. L., Leuchtmann, A., and Spiering, M. J. (2004). Symbioses of grasses with seedborne fungal endophytes. Annu. Rev. Plant Biol. 55, 315-340. doi: 10.1146/annurev.arplant.55.031903.141735

Slaughter, L. C. (2012). Soil Microbial Community Response to Climate Change: Reults From a Temperate Kentucky Pasture. Theses and Dissertations, Plant and Soil Sciences, University of Kentucky. Paper 8. Available online at: http://uknowledge.uky.edu/pss_etds/8

Spiers, D. E., Evans, T. J., and Rottinghaus, G. E. (2005). "Interaction between thermal stress and fescue toxicosis: animal models," in Neotyphodium in Cool-Season Grasses, eds C. A. Roberts, C. P. West, and D. E. Spiers (Ames, IA: Blackwell Publishing), 243-270.

Spyreas, G., Gibson, D. J., and Middleton, B. A. (2001). Effects of endophyte infection in tall fescue (Festuca arundinacea: Poaceae) on community diversity. Int. J. Plant Sci. 162, 1237-1245. doi: 10.1086/323274

Strickland, J. R., Looper, M. L., Matthews, J. C., Rosenkrans, C. F. Jr., Flythe, M. D., and Brown, K. R. (2011). Board-invited review: St. Anthony's fire in livestock: causes, mechanisms, and potential solutions. J. Anim. Sci. 89, 1603-1626. doi: 10.2527/jas.2010-3478

Stuedemann, J. A., and Hoveland, C. S. (1988). Fescue endophyte: history and impact on animal agriculture. J. Prod. Agric. 1, 39-44. doi: $10.2134 /$ jpa1988.0039

Weber, D. A. (2014). Grassland Sustainability in Kentucky: Case Studies Quantifying the Effects of Climate Change on Slug Herbivory in Pastures and Different Home Lawn Types on Turf Greenhouse Gas Emissions. Theses and Dissertations, Plant and Soil Sciences, University of Kentucky. Paper 39. Available online at: http://uknowledge.uky.edu/pss_etds/39

West, C. P. (2007). "Plant influences on endophyte expression," in Proceedings of the 6 th International Symposium on Fungal Endophytes of Grasses, eds A. J. Popay and E. R. Thom (Christchurch: New Zealand Grassland Association (no. 13)), 117-121.

West, C. P., Izekor, E., Turner, K. E., and Elmi, A. A. (1993). Endophyte effects on growth and persistence of tall fescue along a water-supply gradient. Agron. J. 85, 264-270. doi: 10.2134/agronj1993.00021962008500020019x

White, J. Jr. (1987). Widespread distribution of endophytes in the Poaceae. Plant Dis. 71, 340-342. doi: 10.1094/PD-71-0340

Worchel, E., Giauque, H., and Kivlin, S. (2013). Fungal symbionts alter plant drought response. Microb. Ecol. 65, 671-678. doi: 10.1007/s00248-0120151-6

Yates, S. G., and Powell, R. G. (1988). Analysis of ergopeptine alkaloids in endophyte infected tall fescue. J. Agr. Food Chem. 36, 337-340. doi: 10.1021/jf00080a023

Young, C. A., Hume, D. E., and McCulley, R. L. (2013). Forages and pastures symposium: fungal endophytes of tall fescue and perennial ryegrass: pasture friend or foe? J. Anim. Sci. 91, 2379-2394. doi: 10.2527/jas.2012-5951

Yu, J., Chen, L., Xu, M., and Huang, B. (2012). Effected of elevated $\mathrm{CO}_{2}$ on physiological responses of tall fescue to elevated temperature, drought stress, and the combined stresses. Crop Sci. 52, 1848-1858. doi: 10.2135/cropsci2012. 01.0030

Yurkonis, K. A., Shukla, K., Holdenried, J., Hager, H. A., Bolton, K. A., Klironomos, J. N., et al. (2014). Endophytes inconsistently affect plant communities across Schedonorus arundinaceus hosts. Plant Ecol. 215, 389-398. doi: 10.1007/s11258014-0309-z 
Conflict of Interest Statement: The authors declare that the research was conducted in the absence of any commercial or financial relationships that could be construed as a potential conflict of interest.

Received: 10 July 2014; accepted: 23 September 2014; published online: 21 October 2014.

Citation: McCulley RL, Bush LP, Carlisle AE, Ji H and Nelson JA (2014) Warming reduces tall fescue abundance but stimulates toxic alkaloid concentrations in transition zone pastures of the U.S.. Front. Chem. 2:88. doi: 10.3389/fchem.2014.00088
This article was submitted to Chemical Biology, a section of the journal Frontiers in Chemistry.

Copyright (C) 2014 McCulley, Bush, Carlisle, Ji and Nelson. This is an openaccess article distributed under the terms of the Creative Commons Attribution License (CC BY). The use, distribution or reproduction in other forums is permitted, provided the original author(s) or licensor are credited and that the original publication in this journal is cited, in accordance with accepted academic practice. No use, distribution or reproduction is permitted which does not comply with these terms. 